\title{
La paradoja de Pierre Menard: el filme Antígona de Giorgos Tzavellas y la dificultad de adaptar una tragedia griega clásica
}

\author{
Pierre Menard's Paradox: the film Antigone \\ from Giorgos Tzavellas and the difficulty of \\ adapting a classical Greek tragedy
}

\author{
Begoña CAPLLONCH \\ Universitat Pompeu Fabra \\ begona.capllonch@upf.edu \\ ORCID ID: 0000-0001-6908-6517
}

\begin{abstract}
Resumen: A partir del ejemplo de la versión cinematográfica de la Antígona de Sófocles realizada por Giorgos Tzavellas en 1961, una película que hizo gala de una supuesta fidelidad para con la obra original al apartarse del espíritu y la estética del denominado cine péplum, en este trabajo abordaremos la dificultad de adaptar al medio cinematográfico una tragedia ática. Reflexionaremos, asimismo, sobre la revisitación de los clásicos, y consideraremos el asunto de la fidelidad estableciendo una analogía con las interpretaciones historicistas de la música antigua.
\end{abstract}

Palabras clave: Antígona, Giorgos Tzavellas, adaptación cinematográfica, tragedia griega clásica, música antigua.

\begin{abstract}
In this work we will address the difficulty of adapting to the cinematographic media an Attic tragedy, from the version of Sophocles' Antigone by the filmmaker Giorgos Tzavellas in 1961; a film that exhibited its supposed fidelity to the original work by departing from the spirit and aesthetics of the so-called peplum cinema. We will also reflect on the revisitation of the classics and consider the issue of fidelity by establishing an analogy with historicist interpretations of early music.
\end{abstract}

Key words: Antigone, Giorgos Tzavellas, film adaptation, classical Greek tragedy, early music. 


\section{Paradojas y malentendidos en torno a las adaptaciones} FIDEDIGNAS: LA IMPOSIBLE REESCRITURA DE LOS CLÁSICOS

\subsection{De antiguos y modernos}

Con un propósito muy distinto al que perseguían los filmes que la crítica clasificó mediante el apelativo de cine péplum, un subgénero de la cinematografía de tema histórico donde las antiguas civilizaciones eran mayoritariamente utilizadas como pretexto ornamental por su espectacularidad, el realizador ateniense Giorgos Tzavellas rodó su filme Antígona con la pretensión de reflejar con rigor la homónima tragedia de Sófocles; y pese a que en estas páginas cuestionaremos esa presunta fidelidad de la cinta con respecto a la obra original (una fuente ya inaprehensible por la virtualidad de su naturaleza escénica), lo cierto es que la película de Tzavellas, estrenada el 22 de enero de 1961, dio paso a un tipo de largometrajes sobre mitos y tragedias clásicas cuyas realizaciones distan ya mucho de aquellas superproducciones decorativistas ${ }^{1}$ : bastaría recordar la Electra (1962) de Michael Cacoyannis (a la que seguirían otras adaptaciones de asunto helénico como Las Troyanas o Ifigenia) o incluso la Phaedra (1962) de Jules Dassin, una cinta en la que se moderniza el contexto argumental del Hipólito de Eurípides, pero a la que el director logró insuflar el espíritu trágico $^{2}$. Se suele argüir que trabajos como los de Dassin superan ya los rigores de la tragedia para adentrarse en el sentimentalismo melodramático, pero como toda obra adaptada debe necesariamente acomodarse al nuevo lenguaje del medio que la vehiculará, no solo podría transgredir los valores y las convenciones de la categoría a la que se adscribía originariamente, sino incluso asumir los rasgos característicos de los géneros de la disciplina a la que se traslada: este sería el caso, por ejemplo, del filme español Fedra West (1968) de Joaquín Luis Romero Marchent, autor que subsumió la tragedia ática en las coordenadas del wéstern moderno.

La crítica de su tiempo recibió con elogios la Antígona de Tzavellas, al considerar que se trataba de la primera tentativa seria de adaptar cinematográficamente un drama de la Antigüedad clásica. No cabría discusión alguna en cuanto a la necesidad u oportunidad de acudir a una pieza de Sófocles, dado que, como recuerdan Jean-Pierre Vernant y Pierre Vidal-Naquet, estas obras «de los dramaturgos atenienses expresan y a la vez elaboran [...] una nueva forma de comprenderse para el hombre, de situarse en sus relaciones con el mundo, con los dioses, con los otros y también

\footnotetext{
${ }^{1}$ No obstante, y como bien señala María Teresa Magadán Olives (2007: 393-406) en un estudio en el que establece una documentada periodización de la filmografía sobre asunto griego que abarca desde el cine mudo hasta el año 2005, cabe precisar que la visión que divulgaba del mundo helénico el cine péplum era ya muy distinta, por ejemplo, de la que mostraba de la Roma imperial.

2 Algo más tarde hallaríamos las adaptaciones de Edipo Rey (1967) y de Medea (1969) por parte de Pier Paolo Pasolini, pero el personal estilo de la cinematografía del boloñés dificulta su adscripción a cualquier tendencia clasificatoria.
} 
consigo mismo y con sus propios actos» (1989: 88), lo cual no es sino la respuesta a la innecesaria pregunta de por qué las expresiones artísticas son inherentes al género humano. La cuestión de la fidelidad hacia esos modelos de creación de la consciencia trágica, sin embargo, resulta siempre intrincada, dado que cabría postular primero qué requisitos legitimarían la presunta idoneidad de esa fiel traslación. Como apuntaba Robert Stam, el problema es que el discurso sobre la fidelidad para con un obra literaria «se centra en argumentos esencialistas», y esa supuesta esencia que cabría desentrañar es ya pura entelequia, pues todo texto, en suma,

\begin{abstract}
contiene una serie de signos verbales que pueden disparar una plétora de posibles lecturas. Al ser una estructura abierta, constantemente reelaborada y reinterpretada por un contexto ilimitado, el texto alimenta y es alimentado dentro de un intertexto permutado infinitamente, visto a través de la retícula siempre cambiante de la interpretación. De hecho, cuando los críticos se refieren al espíritu o la esencia de un texto literario, a lo que se refieren es al consenso de la crítica dentro de una comunidad interpretativa (Stanley Fish) sobre el significado de la obra (Stam, 2009: 36-37).
\end{abstract}

De hecho, las modernizaciones $-\mathrm{y}$, con mayor motivo, las versiones libres de las obras clásicas-, como parten de un deliberado apartamiento con respecto del modelo original, ya quedan en cierto modo liberadas del compromiso de sujetarse a las leyes -o a la tiranía- del primigenio arquetipo; y aunque suelen ser controvertidas, en verdad ejemplifican la intemporalidad de los clásicos, cuya vigencia no perece porque no dejan de ser elocuentes para cualquier época que los asimila, y no solo en función de lo que entendemos que significaron en su momento, sino sobre todo por lo que significan para el presente en el que se adaptan ${ }^{3}$ : ejemplo palmario sería

\footnotetext{
${ }^{3}$ Como patentizó George Steiner (1987), precisamente la tragedia Antígona ha tenido una fecunda pervivencia en la filosofía, las letras y el arte de la cultura occidental. Además, los conflictos que asolaron a la Europa de la primera mitad del siglo XX supusieron un contexto idóneo para propiciar un sinfín de versiones y recreaciones de carácter denunciatorio. La Antigona (1947) de Bertolt Brecht, por ejemplo, que partía de la traducción alemana que redactó Hölderlin de la tragedia sofoclea, sitúa la acción en el Berlín de 1945, un poco antes de que las fuerzas aliadas ocuparan el territorio alemán. En la de Jean Anouilh, estrenada en París en 1944 -en plena ocupación alemana, por tanto-, la hija de Edipo representa a la Resistencia frente a la figura de un Creonte que simboliza el poder del general Pétain; y en el drama de 1961 del checoslovaco Peter Karvaš, que sitúa la historia en un campo de concentración, Antígona encabeza la rebelión de un grupo de reclutas. Como es lógico, no todas las obras se han amparado en la Segunda Guerra Mundial: la Antígona furiosa (1986) de la bonaerense Griselda Gambaro denunciaba el terrorismo de estado que minó Argentina durante los años de la denominada «guerra sucia»; La tumba de Antígona (1967) de María Zambrano supuso, a la sombra de la Guerra Civil española, una reflexión en torno a un conflicto fratricida y al desarraigo del exilio; y a la luz del mismo acontecimiento, y tomando entonces a Creonte como símbolo del franquismo, cabría leer la Antígona que Salvador Espriu escribió en 1939. La figura de
} 
la libérrima versión de Antígona que recrea I Cannibali (1970) de Liliana Cavani, filme que plasma las aberraciones del poder político y eclesiástico de los tiempos modernos, sembrando de cadáveres las calles de Milán y al compás del himno desenfadado que corea la banda sonora musical de Ennio Morricone. La transtemporalidad de la tragedia antigua reside en que, más que proporcionar ilusorias resoluciones (inevitablemente provisorias y siempre revisables), configuró universalmente la formulación de los cuestionamientos que nos resultan ineludibles, pues «desde la perspectiva trágica, el hombre y la actividad humana no se perfilan como realidades que se pueden circunscribir y definir, [...] sino como problemas sin respuesta, como enigmas cuyos dobles sentidos siempre quedan por descifrar» (Vernant/Vidal-Naquet, 1989: 90). De cualquier modo, si bien la libre versión de un clásico puede parecer ingeniosamente audaz o clamorosamente irreverente, una fallida translación fidedigna siempre nos resulta, en cambio, inadmisible.

\subsection{La finitud del texto y la incompletitud del drama}

Por otra parte, la pretensión de una fidelidad certera - ya irrealizable en sentido estricto- conduciría a la paradoja del Quijote de Pierre Menard ideada por Jorge Luis Borges (1999: 41-55), pues aunque constatáramos que las páginas de Menard coinciden palabra por palabra y línea por línea con las de Miguel de Cervantes, la distancia entre las dos obras siempre sería irreductible: la intemporalidad de un clásico, en efecto, no solo no puede transferirse a la inevitable temporalidad de sus infinitas reescrituras, sino siquiera a su impracticable calco (aunque Menard, como sabemos, nunca se propuso algo tan burdo como transcribir mecánicamente el original cervantino); y en ello radica, de hecho, la estética de la recepción, pues cada época convierte en otro un mismo texto, cual corriente heraclitiana siempre distinta en el fluir temporal. Damos por sentado que Tzavellas - por fortuna- nunca pretendió que su Antígona «calcara» la de Sófocles, pero la cuestión es que el realizador, como veremos, prácticamente reprodujo palabra por palabra y línea por línea el texto del antiguo dramaturgo como si ello pudiera garantizar la fidelidad para con el original. Siguiendo, pues, con el juego de Borges, también un clásico imperecedero que nunca dejó de remedar obras ajenas para ser fiel a sí mismo, podríamos afirmar, sobrescribiendo las palabras de su relato, que «Ser, de alguna manera, Sófocles (Cervantes) y llegar a Antígona (Quijote)» sería «menos arduo [...] que seguir siendo Giorgos Tzavellas (Pierre Menard) y llegar a Antígona (Quijote), a través de las experiencias de Giorgos Tzavellas (Pierre

\footnotetext{
Antígona, en fin, sigue denunciando hostilidades y enarbolando confrontaciones endémicas, como en Le Quatrième mur (2013) del tunecino Sorj Chalandonen, una obra situada en un Beirut en guerra en donde una Antígona palestina y sunita debe convivir con comunidades de chiitas, caldeos y maronitas.
} 
Menard)» ${ }^{4}$. En nuestro caso, además, la obra clásica se transpone a otro código semiológico: al cinematográfico; y como recordaba Leonard B. Mitry, los valores significados por una obra no existen «independientemente de la expresión que los ofrece» (1989: 425-426), por lo que trasladar íntegro el texto no garantizaría la inmutabilidad de su ya lábil sentido. Además, el texto primigenio de Antígona siquiera es «la obra». Ignoramos cuán fiel creyó Tzavellas que podía llegar a ser a una pieza dramática del 442 a.C., pero cabría preguntarse qué debe entenderse por fidelidad, cuando el texto al que hoy se reduce el drama ni identifica ni puede suplantar la naturaleza espectacular del original. Y es que huelga decir que todo texto dramático no supone sino una hipótesis de lo que habrá de convertirse en una realidad escénica, pues incluso el texto más «completo, descriptivo y rico en acotaciones destinadas a su montaje debe considerarse siempre como un esquema» (Bettetini, 1977: 80). Y de ahí que autores como Hans-Thies Lehmann definan el teatro «as a process and not as a finished result, as the activity of production and action instead of as a product, as an active force (energeia) and not as a work (ergon)» (2006: 104). No pretendemos entrar ahora en el debate que mantienen los textocentristas frente a los escenocentristas ${ }^{5}$, sino solo rubricar que cualquier pretensión de fidelidad para con una obra de teatro ya debería presuponer que reescribir el texto no acredita, forzosamente, la plausibilidad de la adaptación. En el caso del drama griego antiguo, además, no solo no hay acotaciones, sino que las palabras únicamente constituían la parte de un ritual celebrativo en el que armonizaban la música, el canto y la imagen ${ }^{6}$. La tendencia a lo que podríamos denominar textualismo, por tanto, carecería aquí de sentido; y aun en el caso de concederle a la palabra escrita una inadecuada autonomía, tampoco resultaría obvio realizar una versión literal o caligráfica, pues siquiera hemos mencionado los escollos de carácter filológico que plantea un texto de la Antigüedad clásica.

\footnotetext{
${ }^{4}$ Hemos recreado, como es manifiesto, un pasaje del texto original del relato «Pierre Menard, autor del Quijote» (Borges, 1999: 50).

${ }^{5}$ Según Stephen Bottoms, los primeros serían los que «abordan la representación concentrándose sobre el lenguaje y las literaturas en las que esta con mucha frecuencia se funda»; y los segundos, «los que consideran el evento de la representación como su principal preocupación y el texto como un simple soporte para este acontecimiento» (citado por Pavis, 2015: 405).

${ }^{6}$ Recuérdese cómo definía Aristóteles la «tragedia» en el capítulo sexto de la Poética (49b24 y sigs.): «Es, pues, la tragedia imitación de una acción esforzada y completa, de cierta amplitud, en lenguaje sazonado, separada cada una de las especies [de aderezos] en las distintas partes, actuando los personajes y no mediante relato, y que mediante compasión y temor lleva a cabo la purgación de tales afecciones. [...] Necesariamente, pues, las partes de toda tragedia son seis, y de ellas recibe su calidad la tragedia; y son: la fábula, los caracteres, la elocución, el pensamiento, el espectáculo y la melopeya».
} 
No obstante, presuponemos que el planteamiento de Tzavellas no era el de realizar una adaptación caligráfica del texto de Sófocles (para empezar, rodó la película en griego moderno y con subtítulos en inglés, por lo que ya prescindió de la musicalidad y cadenciosidad de los versos originales); y que tampoco debió de ambicionar aproximarse al ideal de la reconstitución arqueológica, algo que, como ya apuntó Patrice Pavis, no podría sino responder a una ilusión por la «pura dificultad técnica para reconstruir el pasado y reconstituir el trabajo del actor» (2015: 293). Además, esta reconstitución podría acabar convirtiéndose «en una impostura, en un trabajo puramente formal preocupado por los detalles arqueológicos y no lo suficiente por la nueva relación de la obra con el público y, en consecuencia, la concretización inducida por el cambio de la recepción», motivo por el que, si bien el objetivo de esa supuesta reconstitución habría sido el de acercar la obra clásica a los espectadores, lo que en realidad conseguiría, paradójicamente, es alejarlos al distraerlos con «una visión del pasado» (2015: 294). Esa supuesta reconstitución fidedigna, por consiguiente, en realidad resultaría distorsionadora, dado que le arrebataría a la obra su vitalidad de clásico intemporal para reducirla a un fósil indescifrable (aunque, lógicamente, los criterios que rigen una supuesta reconstitución y los medios con los que esta se lleva a cabo pueden conducir a resultados muy dispares).

Este mismo debate sería extensible a la interpretación de la denominada música antigua (un apelativo ya muy ambiguo además de polémico, en tanto que podría entrar en colisión con el no más preciso de música clásica), aunque, especialmente en sus inicios, se (mal)entendía por defecto que, por el simple hecho de interpretar un tipo de música entonces inaudita, y de ejecutarla a través de reproducciones de instrumentos antiguos, ya se estaba llevando a cabo una reconstitución arqueológica de ese repertorio, lo cual distaba mucho de ser cierto. Esas interpretaciones que se llevaban a cabo mediante lo que entonces se conocía como criterios históricos - ahora se habla de interpretaciones históricamente informadas (un eufemismo parecido para decir lo mismo: que cada músico hace lo que puede, con mayor o menor talento y con mejor o peor conocimiento)- solían llevarse a cabo no en función de las pautas que habrían regido la composición de esa obra en el pasado, sino de cómo desde el presente los músicos las entendían, lo cual ya evidencia un error de planteamiento: ejecutar una obra antigua desde la perspectiva presente no es necesariamente inadecuado, siempre y cuando no se confunda con el hecho de tratar de ejecutarla en función de cómo esos parámetros debieron de entenderse en la época en la que se establecieron ${ }^{7}$.

\footnotetext{
${ }^{7}$ Esta cuestión la denunció ya Richard Taruskin en un incendiario artículo que, publicado en The New York Times el 29 de julio de 1990, llevaba por título «The Spin Doctors of Early Music». El libelo se divulgó más tarde en otras fuentes - y con algún epílogo aclaratorio- bajo el epígrafe de «The Modern Sound of Early Music», pero el texto original puede consultarse en el siguiente enlace:
} 
Ciertamente, la dimensionalidad que entraña rodar un largometraje multiplica de manera exponencial las complicaciones a las que debe enfrentarse un intérprete musical (aunque quizás se aproximaría a la labor que asume un director de orquesta), pero en ambos casos, un individuo del s. XXI debe tomar una serie de decisiones con respecto a una obra que no constituye ya un hecho, sino una hipótesis (en un caso, basado en la espectacularidad de un drama; en otro, en la delicuescencia de un sonido); y la huella de esa hipótesis más o menos desdibujada -cuando no prácticamente desleída- se reduce a los símbolos de un texto o de una partitura. Evidentemente, los paratextos pueden ayudar a esclarecer los restos gráficos de esa entidad intangible, pero deben igualmente interpretarse y son susceptibles de tergiversarse o confundirse. En nuestro caso, además, la ejecución de esa partitura original se traslada a otro ámbito (del teatral al cinematográfico), una cuestión a la que regresaremos más adelante. Pero examinemos, en primer lugar, las características de la película de Tzavellas.

\section{La engañosa literalidad del Planteamiento de TZavellas: el DELIBERADO ANTINATURALISMO DEL FILME}

\subsection{La sujeción a la historia y la textualidad de las imágenes}

Giorgos Tzavellas, que formaba parte del grupo de directores que integraba la denominada Escuela de Atenas junto con Nikos Tsiforos y Alekos Sakellarios, se propuso rodar Antígona animado por el hecho de que el Teatro Nacional griego estaba entonces recuperando los dramas antiguos tanto en Epidauro como en el Odeón de Herodes Ático (Valverde García, 2009: 178), y buena parte del equipo técnico y del elenco de su película procede, precisamente, de las filas de ese Teatro $\mathrm{Nacional}^{8}$. Y aunque su obra, como habíamos apuntado, se aleja ya del espíritu del cine péplum, no escapa por completo, al menos formalmente, a la estética de esa tradición monumentalista, pues gracias al cuantioso presupuesto del que dispuso, se pudieron contratar a los casi 500 extras que participaron en la cinta - entre los que se encontraban incluso los jinetes de la Guardia Real Griega- y que poblaban esa Tebas de cartón piedra que se construyó ad hoc en los estudios

https://www.nytimes.com/1990/07/29/arts/the-spin-doctors-of-earlymusic.html [Fecha de consulta: 31/10/2020].

${ }^{8}$ Conforman los créditos de la película la siguiente relación de personas (no ofrecemos, lógicamente, la lista exhaustiva): Irene Papas (Antígona), Manos Katrakis (Creonte), Nikos Kadsís (Hemón), Maro Kondú (Ismene), Tsavalas Karusos (Tiresias) e f́lya Livykú (Hermíone). Y asimismo, Giorgos Tsaoulis (Montaje), Dínos Katsourídis (Fotografía), Giorgos Anemogiannis y D. Stavropoulo (Vestuario), Giorgos Anemogiannis (Decorados), Argyris Kounadis (Música), Thanassis Georgiadis (Sonido) y Demetrios Paris (Producción). 
Alfa de Atenas (Valverde García, 2009: 178-179)9 ${ }^{9}$. No obstante, el deliberado uso del blanco y negro supuso ya toda una declaración de intenciones, pues era el aviso, como veremos, de que era el texto lo que el director pretendía enfatizar.

En realidad, la fidelidad por la que apostó Tzavellas se reduce a seguir la trama de la Antígona sofoclea (los personajes y el modo en que se suceden los acontecimientos se ciñen a la forma en que se inscriben en el original) y a no reinterpretar la tragedia mediante el prisma de ninguna clave conceptual o simbólica ajena al mythos. Y de acuerdo con este planteamiento, el guion del filme reprodujo, servilmente, el texto de Sófocles vertido al griego moderno en una adaptación del propio Tzavellas, ya guionista experimentado. Con todo, el medio audiovisual le proporcionaba al realizador muchos recursos para «ilustrar» ese texto, y la película, en efecto, es pródiga en recreaciones que lo apostillan: para empezar, Tzavellas opta por transcribir visualmente todos los pasajes no miméticos de la obra (esto es, los que se relatan sin ser representados), en lugar de filmar el parlamento mismo, por lo que los tres acontecimientos del pasado que se verbalizan en Antígona se dramatizan cual comunes flashback cinematográficos: así, observamos cómo la hija de Edipo le rinde honores a su hermano Polinices y es apresada, mientras lo reporta el asustadizo guardia; asistimos a las funestas revelaciones experimentadas por Tiresias, y vemos cómo Hemón se atraviesa una espada -aunque, en este caso, de espaldas al espectador-, mientras la voz en off del mensajero lo narra, motivo por el que podríamos concluir que la cinta relata con imágenes lo que el decoro ocultaba mediante las palabras. Como argumenta Fernando García Romero (1998: 200-202) aduciendo ejemplos de Cacoyannis y Pasolini, poner en imágenes tanto los prólogos como los parlamentos de los mensajeros es algo muy común en las versiones cinematográficas de las tragedias clásicas - que no del teatro filmado-, pero en la cinta que nos ocupa, la argucia pretendía, paradójicamente, no potenciar la imagen, sino utilizarla para resaltar el texto. Asimismo, Tzavellas opta por dramatizar tanto la párodos inicial como los estásimos, pues vemos cómo personajes o situaciones recrean lo referido por el corifeo y el coro; y también somos testigos de otros acontecimientos mencionados por los versos, como el honorífico ritual fúnebre que recibe Eteocles según lo decreta Creonte. De hecho, y aparte de algunas dramatizaciones quizás excesivas y un tanto fantasiosas, la única licencia manifiesta que se toma Tzavellas es la que desvelan las últimas secuencias de la película, pues sin que esta vez lo refrenden los versos de Sófocles, somos testigos de cómo Creonte, ya cadáver animado, se desposee de su tiara y la deja caer al suelo. A continuación, saldrá del palacio donde ya no se distingue del resto de los

\footnotetext{
${ }^{9}$ En torno a esta cuestión, vid. el recorrido que traza Alejandro Valverde García (2012: 251-271) de la filmografía sobre el mundo griego a partir, precisamente, de las obras que rodaron directores griegos (y, en especial, en la década de los 60).
} 
ciudadanos (la corona era el lábil atributo que engañosamente lo diferenciaba de sus congéneres) y, finalmente, franqueará las puertas de la ciudad escenificando así un autodestierro que lo iguala a Edipo, no en vano el padre de la mujer a la que ha enviado a la muerte. En el último plano, rodado con cámara fija, lo veremos alejarse, de espaldas, adentrándose en una tierra sin nombre.

\subsection{El buscado antiverismo y la vocación pedagógica del filme}

Ciertamente, las distintas recreaciones a las que da imagen Tavellas ayudan a suavizar los raccords, aunque también dan contextura a la obra reforzando o subrayando la trama que con tanta intensidad condensa Sófocles. La prolijidad visual, pues, parece compensar el deliberado antinaturalismo de las actuaciones, pues en la línea no realista de Max Reinhardt, la impostación de los actores y su porte declamatorio los sitúa, en efecto, al margen de la expresión directa de la cotidianeidad (lo cual propicia, por otro lado, que puedan encarnar su condición de arquetipos). Así pues, y pese a que esa falta de naturalidad fue objeto de crítica, en realidad era un modo de elevar a los personajes a la tesitura de héroes trágicos que les correspondía; y en lo mismo abunda el Blanco y Negro de la cinta que tanto contradeciría el colorismo del espectáculo original de Sófocles, aunque quizás el excesivo artificio con el que se presenta la figuración de la película (los envarados atuendos, las atusadas cabelleras...) le resta a la obra la gravedad pretendida, dado que lo que se presumía caracterización se resuelve disfraz. Asimismo, tampoco es verosímil el tratamiento de la música, puesto que todos los bloques musicales son extradiegéticos (o de foso $)^{10}$; no obstante, en alguna ocasión se simula que la música es diegética (o de pantalla), como si de veras la estuvieran escuchando los personajes, como en la escena del Episodio I contextualizada en el palacio de Creonte justo antes de que llegue el asustadizo guardia para denunciar que alguien ha hecho una libación para el cuerpo de Polinices: en ese momento, una joven está tocando un aulos, aunque lo que suena no se corresponde exactamente con la fuente sonora visible ni con el modo en que la muchacha emplea el instrumento.

Tzavellas, en verdad, no escatima en apuntes explicativos o aclaratorios, y de ahí que todos los bloques musicales de la película subrayen la tesitura emocional de las escenas e incluso preparen al espectador advirtiéndolo de los acontecimientos funestos. De hecho, incluso los movimientos de la cámara tratan de ser explicativos, como cuando Antígona está ya encerrada en la roca y se nos avisa de que está próximo su ahorcamiento al detenerse el plano sobre el velo que habrá de servirle de soga. Asimismo, esa vocación

\footnotetext{
${ }^{10}$ La terminología en torno al modo en que la música se relaciona con la diégesis fílmica es muy amplia; sobre esta cuestión y los términos empleados por los distintos teóricos (nosotros ponemos entre paréntesis los acuñados por Marcel Chion), vid. Alunno (2005: 15-24).
} 
pedagógica de la cinta también se delata en la argucia de su inicio: la Antígona sofoclea comienza in medias res, habida cuenta de que el público de su época era perfectamente conocedor de las entrañas del mito, y Tzavellas, con el fin de proporcionar esa información que presupone ignorada, opta por referir esa protohistoria antes del comienzo de la acción. Así pues, y tras los créditos (precedidos por el logo de la productora Norma Film: precisamente, una máscara del antiguo teatro griego), unas imágenes que reproducen las de las prototípicas figuras que decoraban los vasos áticos van ilustrando, acompañadas por sobretítulos, el destierro de Edipo y el litigio entre sus dos hijos varones; y todo ello sazonado con una banda sonora musical en la que prevalece, claro está, una lira: uno de los instrumentos más significativos de la Antigüedad helénica. De este modo, el realizador se aseguraba de la «correcta» comprensión del comienzo ex abrupto de la tragedia; de una historia que Tzavellas enfatiza, además, con las subsiguientes imágenes de los restos de una batalla en los extramuros de la ciudad de Tebas entre los que se distingue una incólume figura vestida de blanco que corresponde, como adivinamos, a Antígona.

De cualquier modo, y como ya exponíamos más arriba, en ningún caso Tzavellas pretende inocular verismo en lo que filma: ni trasladando la trama a la realidad del público de los años 60 -lo que correspondería a una historización, opuesta a la reconstitución arqueológica (Pavis, 2015: 294)-, ni tratando de recrear ese pasado histórico; en todo caso, ofrecía, desde su tiempo y para sus contemporáneos, la idea que él juzgaba fiel -aunque a nosotros nos parezca ya estereotipada- de ese pasado histórico; y de ahí no solo la bicromía y la solemnidad gestual de los actores, sino incluso la vocación pedagógica de la película, que guía al espectador en los afectos con la música- y propicia la comprensión de la trama al subrayar con imágenes los pasajes no miméticos del original (como los que corresponden al parlamento de los mensajeros). Probablemente, mediante esa ausencia de verismo y su sujeción al texto de Sófocles, Tzavellas pretendió trasladar al filme la esencia trágica del drama; una cuestión, sin embargo, nada elemental, como consideraremos a continuación.

\section{LOS PROBLEMAS DE ADAPTACIÓN DE LAS CONVENCIONES DE LA TRAGEDIA: DE LA PALABRA A LA IMAGINACIÓN \\ 3.1. El conflicto trágico y la función del coro}

En el drama ático, el sentido trágico se descubre, como sabemos, en «la tensión de fuerzas contradictorias a la que el hombre está sometido» (Vernant/Vidal-Naquet, 1989: 94), motivo por el que, como señalan Juan Pedro Enrile Arrate y Alfredo Fernández Sinde (2009: 207 y sigs.), entre los elementos que deberían resolverse satisfactoriamente en cualquier puesta en escena (o versión cinematográfica) contemporánea de una tragedia de la Grecia antigua cabría destacar, en primer lugar, la expresión de ese conflicto irresoluble entre fuerzas contrarias que alienta toda la acción; y, complementariamente a esta premisa, que se consiguiera que los actores que 
representan ese conflicto lo interpretaran a través del ideal de grandeza que es el propio de los héroes trágicos, quienes no se mueven en la cotidianeidad, sino en una tesitura superior: «son personajes que prescinden de amoldarse a los cauces comunes, de regirse por lo previsible dentro de una sociedad dada, son personajes que se despreocupan de lo que llamamos realidad, y se mueven en un ideal de grandeza» (2009: 208). Así pues, en el caso que nos ocupa, podríamos decir que los dos protagonistas, Irene Papas (Antígona) y Manos Katrakis (Creonte), cumplen perfectamente con el requisito exigido, e incluso podríamos añadir que, a nuestro juicio, la magnanimidad que desprende en esta cinta el personaje de Creonte se equipara mejor a la de su émula Antígona que en el texto de Sófocles, dado que, en el drama original, la figura del tirano enflaquece ante el arrojo y las convicciones de la hija de Edipo (especialmente, en el pulso que sostienen, en el Episodio II, durante su enfrentamiento en el palacio). En el filme de Tzavellas, de hecho, es Creonte, a nuestros ojos, el personaje que de manera más flagrante experimenta la violencia del conflicto trágico en el que se desarrolla el pathos (sobre todo, en las últimas escenas), y ello pese al hieratismo de su enjuto rostro, que se diría esculpido en piedra. En lo tocante a Antígona, en cambio, parece que es su belleza lo que la sitúa, en la película, al margen del resto de los individuos, pues si bien no tenemos por cometido enjuiciar aquí el trabajo de la actriz, es manifiesto que será en las adaptaciones realizadas por Cacoyannis donde Papas despuntará. No obstante, tanto Creonte como Antígona hacen gala, en esta cinta, del rango y del valor que deben identificar a los héroes trágicos, tal y como lo apuntó Aristóteles en el capítulo quince de la Poética; y hacen creíble la desmesura (hybris) por la que habrán de sucumbir.

Asimismo, el elemento de la tragedia ática con el que debe lidiar insoslayablemente cualquier versión cinematográfica de la misma es, claro está, la instancia coral; un componente que, como rubricó Schlegel, actúa cual «espectador idealizado. Mitiga la impresión de una representación profundamente estremecedora o profundamente conmovedora, al oponer al espectador sus propias emociones expresadas líricamente, es decir, musicalmente, trasladándolo al lugar de la reflexión» (reproducido en Zimmermann, 2012: 123). En nuestra actual cultura, sin embargo, nada hay «equiparable a la importancia de los coros en la vida social y religiosa» (García Romero, 1998: 194), motivo por el que, salvo en los casos de teatro filmado, donde los coros se suelen preservar con mayores o menores innovaciones (como en Los Persas de Jean Prat o en Edipo Rey de Tyrone Guthrie), o bien se suprimen, o bien se adaptan como diálogos entre varios personajes. Y es que, como señala García Romero, con los recursos propios del arte cinematográfico, «el coro pierde por regla general buena parte del papel que tenía asignado en la tragedia antigua», y aunque en tales filmes «no falta, de una u otra manera, la presencia física de un coro, $[\ldots]$ su función queda muy disminuida o considerablemente adulterada» (1998: 196). Como habíamos apuntado, la información referida por el coro es 
asumida, en la cinta de Tzavellas, por diferentes personajes, por lo que, como precisa el mencionado investigador, aunque en la película del ateniense «aparece, sí, un coro», este

\begin{abstract}
no es tratado como una unidad (no se mueve coreográficamente ni canta), sino como un grupo de varios individuos que conversan entre sí y comentan la acción según el parecer de cada uno de ellos, como sucede en el estásimo primero; [y] otras veces las partes corales del original son sustituidas por monólogos o, como en la Electra de Ughetto, por los comentarios de una voz en off (García Romero, 1998: 196).
\end{abstract}

Ciertamente, con respecto de su antecesor Esquilo, Sófocles ya redujo la relevancia funcional del coro, pero no su presencia coadyuvadora para con la tesitura emocional de los personajes, pues no en vano una de sus innovaciones fue la de ampliar el número de coreutas. Tzavellas, sin embargo, desbarata el cometido original del coro al transformarlo en un pasaje de tránsito que permite, eso sí, engarzar los distintos episodios. No obstante, y teniendo en cuenta que no se trataba de realizar una reconstitución arqueológica del drama primigenio, no hubiera tenido mucho sentido preservar los coros en su forma y función originales, dado que estos tienen significado, precisamente, en el marco genuino de la tragedia antigua. Acomodarlos a la narrativa del lenguaje audiovisual en el que ahora se insertan no nos parece una solución desatinada, puesto que más incongruente hubiera sido introducirlos a la manera de Sófocles pero fuera de la estructura original. El problema, con todo, es que la forma en que los transforma Tzavellas resulta algo artificiosa, por lo que los coros acaban asimilándose a la ambientación contextual del filme.

\title{
3.2. La tiranía de la littera y el ejemplo de una tragédie en musique
}

En cualquier caso, lo que evidencia la película de Tzavellas es que la fidelidad al texto por la que apostó el director no solo se resiste a adaptarse a la narrativa cinematográfica, sino que ya entraría en contradicción con el drama mismo, dado que, como hemos ya apuntado, las palabras eran solamente uno de los componentes de la tragedia clásica, que no el eje al cual el resto de los elementos se supeditaba. El director le atribuye al filme la tiranía de la littera con la que, inadecuadamente, se suelen asimilar las obras dramáticas como si fuesen textos literarios autónomos, pero no hay que confundir la materia textual con la realidad escénica. De ahí que la teoría teatral moderna distinga diferentes niveles de texto dramático: «the linguistic text, the text of the staging and mise en scène, and the "performance text"» (Lehmann, 2006: 85), siendo este último el que se concretaría en una situación real y en su interacción con el resto de los componentes de esa actuación. Aunque el medio cinematográfico es, al igual que el dramático, visual, Tzavellas tomó la fuente sofoclea considerándola como una obra finita -que no como un esbozo de espectáculo-; posteriormente, revistió ese texto con los atuendos, utilería y decorados que 
conforman el repertorio de tópicos de la imaginería griega, tal y como los había codificado su tiempo. El resultado no causa extrañeza, porque precisamente reconocemos e identificamos esos tópicos que vinculamos al mundo heleno, y porque podemos confirmar que el guion reproduce el texto de Sófocles que nos proporcionan nuestras socorridas ediciones, por lo que tomamos por fidelidad lo que en realidad no es sino identificación o reconocimiento: reconocemos, sí, los elementos que utiliza Tzavellas para versionar el clásico, lo cual no significa que su película sea fiel al original. Sencillamente, se identifica mejor el modelo que en el caso de la película $I$ Cannibali, porque todos los personajes, parlamentos y sucesos que filma Tzavellas estaban ya en la obra de Sófocles. En la cinta de Cavani, en cambio, debemos hacer un esfuerzo abstractivo para suplir el hiato que se manifiesta entre la antigua Tebas del s. V a.C. y la delirante Milán de los años 70. No estamos afirmando, evidentemente, que la cinta de Cavani sea más fiel que la de Tzavellas (la realizadora italiana, además, tampoco lo pretendía: se trata claramente de una inspiración); lo que tratamos de argüir es que las obviedades de la película de Tzavellas no la convierten forzosamente en una adaptación fidedigna. Lo que cabría plantearse, sin embargo, es hasta qué punto sería operativa, si es que fuera en verdad posible, esa acreditada fidelidad.

En el caso de que se tratara de una reconstitución arqueológica (que, como ya apuntó Pavis, no está exenta de dificultades), tendría validez, precisamente, en tanto que evidencia arqueológica fechada y catalogada, que ya no como obra clásica intemporal. Podríamos traer a colación, por ejemplo, la extraordinaria reconstitución arqueológica de la obra Atys (1676) de Jean-Baptiste Lully (con libreto de Philippe Quinault) que en 2011 realizaron, en la Opéra-Comique de París, el director de escena JeanMarie Villégier, el director musical William Christie y el conjunto instrumental Les Arts Florissants. Esta tragédie en musique (un género que pretendía emular, precisamente, la esencia de las tragedias clásicas), basada en los Fasti de Ovidio, es un espectáculo en el que conciertan música, danza, palabra e imagen, y los directores lo llevaron a cabo tras un minucioso análisis de diversas fuentes documentales en torno a su puesta en escena en el s. XVII, luego atendiendo a la coreografía, decorados, vestuario, uso de los instrumentos, gestos actorales, dicción, etc. La exquisita lectura de la obra que ofrecieron los directores posee un valor incalculable, pero todos y cada uno de los elementos que la componen significan en función de las coordenadas de la época en la que la obra surgió y de las circunstancias contextuales en que se representaba, por lo que, aun tratándose de un clásico, la pieza no entraña la universalidad que convoca la tragedia sofoclea. No se trata, evidentemente, de establecer agravios comparativos, sino de constatar una serie de evidencias. Esa versión del drama Atys es poco accesible, porque reclama la asunción de un código previo cuyo desciframiento conducirá a la cabal comprensión de todos sus elementos. Por supuesto, un espectador sin la instrucción específica podría caer rendido 
ante la belleza del espectáculo, aunque, por lo común, no comprenderá a qué se deben, por ejemplo, la falta de dinamismo de la danza, la extrema artificiosidad de la distribución escénica de los personajes, el amortiguado volumen de la sonoridad o el extraño diálogo entre las voces planas de los cantantes y la elocución desacompasada de los instrumentos, dado que todo ello se aleja completamente del modo en que la tradición occidental ha ido educando el oído moderno (y, sobre todo, tras el Romanticismo). Todos los parámetros del espectáculo tienen, en efecto, un sentido, pero este se resuelve en el contexto de la tragédie en musique del s. XVII - un género, además, específicamente francés y en honor a la monarquía gala- y no en el s. XXI (y ni siquiera en la idea que, en el s. XXI, se tiene del espectáculo barroco en general). No estamos afirmando, nada más lejos de ello, que la supuesta mayor o menor inteligibilidad de una obra para el público de una época deba condicionar los criterios de adaptación de la misma, dado que no es nuestro objetivo entrar en consideraciones de índole sociológica. Asimismo, tampoco tenemos interés alguno en enjuiciar la labor de un realizador frente a otros, pues de lo que se trata, en suma, y más allá de medir el alcance de la fidelidad para con un espectáculo del pasado, es de reflexionar en torno al valor epistemológico de un montaje dramático o de una propuesta cinematográfica.

\subsection{De la representación escénica a la virtualidad audiovisual}

Por otra parte, y como nos hemos referido más arriba, la cinta de Tzavellas enfatiza el hieratismo de los rostros y la ceremoniosidad de algunos gestos que abundarían en la teatralidad de la película, pues el trabajo actoral de las representaciones dramáticas exige una definición del ademán y de la posición escénica mucho mayores que la del medio cinematográfico, que puede recurrir, como sabemos, a los primeros planos - una técnica que, además, le imprime a la imagen mucha carga afectiva, tal y como lo señaló Eisenstein (citado por Deleuze, 1983: 125)-. Esa supuesta teatralidad de la película, sin embargo, que fue otro de los recursos que utilizó Tzavellas para ser fiel al original, se resuelve falaz en la pantalla. Ciertamente, el cine comparte con el teatro algunos de sus rasgos idiosincrásicos, pues ambas disciplinas se desarrollan en la espectacularidad (son medios, en efecto, para spectare) y presuponen, teóricamente, la concurrencia del espectador en un espacio colectivo en el que este experimentará tanto lo que sucede en el espacio de lo representado (el escenario, la pantalla) como lo que ocurre en el lugar de la representación (el teatro, la sala de proyecciones), pues también el propio espectador asiste al sentir del público. Indudablemente, son también muchos los elementos que distancian uno y otro arte, pues el cine no entraña el carácter irrepetible de la interpretación teatral, que por mucho que se represente no puede ofrecer espectáculos idénticos. Cierto es que el espectador de la obra cinematográfica puede vivir una experiencia estética análoga a la del público del teatro. Esa experiencia estética, que sería el equivalente moderno de la antigua catarsis (y la kátharsis era, como 
sabemos, la verdadera finalidad de toda tragedia ática), podría vivirla el espectador cinematográfico con la misma intensidad que el público de un teatro, frente al impacto emocional causado por la obra que estuviera desarrollándose ante sus ojos de forma simultánea a la percepción de la misma, pero el carácter vivo del drama difiere, lógicamente, de la naturaleza exánime de la cinta de celuloide: en un teatro, lo acontecido no solo tiene lugar ante los ojos del público, sino «revistiendo las formas de la existencia real en la actualidad del espectáculo» (Vernant/Vidal-Naquet, 1989: 91); y en el ámbito de la tragedia antigua, además, aquello que la palabra convocaba remitía a un pasado mítico cuya inexcusable ausencia justificaba, precisamente, la presencia efectiva de unos personajes en una escena (que no su presencia virtual en la pantalla de una sala de proyecciones). Por otra parte, en el teatro también los ejecutantes están experimentando la interpretación de la obra a la vista de los espectadores, lo cual significa que esa pieza no solo podrá ir transformándose a medida que se construye (lo que podríamos entender como una reconstrucción vertical), sino que seguirá transformándose a lo largo del tiempo en que se represente (en la historia de las representaciones, en su reconstrucción horizontal), puesto que esa indeterminación del texto a la que tanto nos hemos referido aquí le garantiza, precisamente, su vitalidad y mutabilidad. La cinta cinematográfica, en cambio, constituye, en su forma, un cuerpo virtual invariable, pese a que no podrá eludir, paradójicamente, los efectos del paso del tiempo. Sea como fuere, la teatralidad del filme de Tzavellas no solo no acerca la película al drama original, sino que la desvirtúa del medio cinematográfico a la que pertenece.

Finalmente, y aunque suponga una obviedad que por notoriamente sabida casi es necedad expresarla, lo que llevó a cabo Tzavellas, como haría cualquier otro cineasta o director de escena, fue atribuirle al drama de Sófocles la dimensión visual de la que el texto -que no la obra en su realización natural- carece. Como recordaba José Luis Sánchez Noriega (2000: 39), «la mayor diferencia del valor de los sintagmas verbales respecto a los visuales [...] radica en la analogía de la imagen. Se suele decir que la palabra se sitúa en un nivel de abstracción, mientras que la imagen es concreta, representacional, remite directamente a un referente». Tzavellas, en efecto, tradujo unos versos, unas palabras, en unas imágenes de ineludible concreción que, aunque reducen a una sola realidad la infinidad de posibilidades referenciales del texto original, no dejan de constituir, en puridad, la resulta de un acto imaginativo. Y partiendo de este hecho, apelar a la fidelidad en términos tradicionales ya supone, consecuentemente, una aporía. En verdad, lo mismo ocurría en cada representación del drama antiguo, puesto que, siendo la tragedia esa «simulación de un sistema coherente de acciones encadenadas que conducen a la catástrofe», y por las que «la existencia humana accede a la consciencia» de sí misma, esta solo tendría lugar, precisamente, a través del montaje de esa experiencia imaginaria que constituye toda representación (Vernant/Vidal-Naquet, 
1989: 95). En consecuencia, tal vez el único modo de ser fiel a una tragedia antigua sería, paradójicamente, el de recurrir a las traiciones de la imaginación.

\section{CODA}

El hecho de que hayamos cuestionado la pretensión de fidelidad de la versión de Tzavellas no significa, pese a todo, que anatemicemos su propuesta o que no reconozcamos la valía de su trabajo. El problema es que el concepto de «fidelidad» presupone el de «verdad», pues como precisa Pavis, solo asumiendo «la idea de una verdad del texto, inscrita en él, indiscutible e inalienable», tendría sentido concebir «una necesaria y posible fidelidad de la interpretación» (2015: 406). Esa presunta fidelidad, pues, se basaría en la ilusión de que podemos estar «leyendo, interpretando y actuando la obra conforme a las intenciones del autor, como si existiera una lectura correcta, una lectura que no traicionara una verdad verificable en la pieza dramática o en la obra interpretada» (2015: 406). No existen, como sabemos, posibles lecturas correctas o unívocas, pues las obras ni convocan ni entrañan esa verdad que sería inapelable y a la que cabría rendir pleitesía. El dominio de la «verdad», además, es ya ajeno a la literatura, pues como expresaba Alfonso Reyes mucho antes de que surgieran los estudios sobre las modalidades ficcionales y la teoría de los mundos posibles, «la experiencia psicológica vertida en una obra literaria puede o no referirse a un suceder real. Pero a la literatura tal experiencia no le importa como dato de la realidad, [...] sino porque es interesante en sí misma» (1952: 86).

A tenor de todo lo expuesto, y relegando ya el asunto de la aporética fidelidad, la cuestión es que, en lo que concierne a las transposiciones escénicas o cinematográficas de los clásicos, nosotros no defendemos a ultranza una supuesta sujeción al modelo. El respeto por la obra y por su tradición no implican necesariamente que cada (re)lectura deba hacerse en los medios y con los criterios de la pieza original. De ser así, las Variaciones Goldberg de J. S. Bach, una composición concretamente intitulada Aria mit verschiedenen Vercenderungen vors Clavicimbal mit 2 Manualen (porque debía ejecutarse, en efecto, con un clavicémbalo de dos teclados), nunca hubiera podido interpretarse al piano $\mathrm{y}$, en consecuencia, nos hubiéramos visto privados de las singulares e iluminadoras versiones de Glenn Gould (cuya interpretación, por cierto, permite reflexionar acerca del sistema de composición de Bach, y hasta sobre el modo de articular, incluso con el clavicémbalo, las diferentes voces de la partitura). Siguiendo las especificaciones del compositor de Leipzig, la pieza siquiera podría interpretarse con un cembalo italiano (demasiado percutido) o con cualquier otro clavicémbalo de un solo teclado. En cuanto a las versiones escénicas o cinematográficas, cierto es que nosotros preferimos las adaptaciones modernas, las muy personales o, incluso, las recreaciones libres, a las presuntas transposiciones (pseudo)fieles, pues estas acaban por proyectar una imagen falaz de la obra, y más cuando se autoproclaman dignas de 
crédito. Muy distintas son, ciertamente, algunas lecturas que podríamos denominar filológicas como la que hicieron Villégier y Christie del Atys lullyano, que es una reconstrucción tan espléndida como excepcional (aunque no menos extraordinarios debieron de ser los medios materiales y económicos con los que contó, fuera del alcance de la mayoría de los teatros). Por otra parte, la variedad de los distintos enfoques de las diversas adaptaciones muchas veces permite descubrir nuevos puntos de vista o ahondar en los viejos dilemas; $\mathrm{y}$, asimismo, a veces los clásicos se nos revelan sin que siquiera se haya pretendido aludir a sus ubicuos ancestros, pues como apunta García Romero, acaso el mejor reflejo cinematográfico de una tragedia antigua lo patentizan los filmes de Eisenstein y, especialmente, sus dos partes de Iván el Terrible

con los gestos y movimientos estilizados, pausados y enfáticos de los actores, los rostros de mirada fija y hieráticos como máscaras, los movimientos y disposición coreográficos de los grupos que representan al pueblo o a los boyardos, y también sus cantos y danzas corales, monodias y amebeos (con el solista incluso enmascarado), perfectamente integrados en la acción (1998: 203).

Borges (o, mejor dicho, el otro Borges, ese al que le ocurren las cosas) precisaría que este ejemplo es uno de los muchos que demostraría esa «técnica del anacronismo deliberado y de las atribuciones erróneas» con la que Menard enriqueció - sin querer- ese maravilloso «arte detenido y rudimentario de la lectura» (1999: 55), y que nos impelería, en efecto, a aprehender las obras cual corriente continua de prolepsis y analepsis, aunque nosotros ya nos conformábamos con esas palabras de Menard en torno a que «Pensar, analizar, inventar»-léase adaptar, recrear, imaginar...«no son actos anómalos», sino «la normal respiración de la inteligencia» (1999: 55).

\section{Bibliografía CITADA}

Alunno, Marco (2005), «Reflexiones alrededor de la diégesis del sonido en el cine», en Teresa Fraile y Eduardo Viñuela (eds.), Relaciones música e imagen en los medios audiovisuales, Oviedo, Universidad de Oviedo, págs. 15-24.

Aristóteles (2010), Poética, ed. trilingüe de Agustín García Yebra, Madrid, Gredos.

Bettetini, Gianfranco (1977), Producción significante y puesta en escena, trad. de Juan Díaz de Atauri, Barcelona, Gustavo Gili.

Borges, Jorge Luis (1999), «Pierre Menard, autor del Quijote», en Ficciones, Madrid, Alianza, págs. 41-55.

Deleuze, Gilles (1983), Cinéma 1. L'image-Mouvement, París, Éditions de Minuit. 
EnRILE ArRate, Juan Pedro y Alfredo Fernández Sinde (2009), Arquitectura de espectáculo y puesta en escena en la Antigua Grecia, Madrid, Fundamentos.

García Romero, Fernando (1998), «Adaptaciones cinematográficas de la tragedia griega: puesta en escena antigua y moderna», en Elsa García Novo e Ignacio Rodríguez Alfageme (eds.), Dramaturgia y puesta en escena en el teatro griego/Drammaturgia e messa in scena nel teatro greco, Madrid, Ediciones Clásicas, págs. 193-203.

Lehmann, Hans-Thies (2006), Postdramatic Theatre, introd. y trad. de Karen Jürs-Munby, Taylor \& Francis e-Library [En línea: https://monoskop.org/images/2/2d/Lehmann HansThies Postdramatic Theatre.pdf. Fecha de consulta: 27/10/2020].

MagadÁn Olives, María Teresa (2007), «El mundo griego en la cinematografía griega y occidental: paralelismos y divergencias», en Javier Alonso Aldama y Olga Omatos Sáenz (eds.), Cultura Neogriega. Tradición y modernidad. Actas del III Congreso de Neohelenistas de Iberoamérica, Bilbao, Universidad del País Vasco, págs. 393-406.

Mitry, Leonard B. (1989), Estética y psicología del cine. 2 Las formas, trad. de Mauro Armiño, Madrid/México, Siglo XXI.

Pavis, Patrice (2015), La puesta en escena contemporánea. Orígenes, tendencias y perspectivas, trad. de Magaly Muguercia, Murcia, Editum.

REYES, Alfonso (1952), «Apolo o la literatura», en La experiencia literaria, Buenos Aires, Losada, págs. 85-105.

SÁnCheZ Noriega, José Luis (2000), De la literatura al cine. Teoría y análisis de la adaptación, Barcelona/Buenos Aires/México, Paidós.

STAM, Robert (2009), Teoría y práctica de la adaptación, trad. de Florencia Talavera, México, UNAM [En línea: http://guion2.weebly.com/uploads/1/5/0/9/15091428/teora y practica de la adaptacin.pdf. Fecha de consulta: 02/11/2020].

Steiner, George (1987), Antígonas. Una poética y una filosofía de la lectura, trad. de Alberto L. Bixio, Madrid, Gedisa.

Taruskin, Richard (1990), «The Modern Sound of Early Music», The New York Times, 29/07/1990 [En línea: https://www.nytimes.com/1990/07/29/arts/the-spin-doctors-ofearly-music.html. Fecha de consulta: 31/10/2020].

Valverde García, Alejandro (2009), «Antígona de Yorgos Tzavelas, un instrumento didáctico para la prevención y resolución de conflictos», Estudios Neogriegos, 12, págs. 173-188.

VALVERDE GarcíA, Alejandro, «Grecia Antigua en el cine griego», Thamyris, n. s., 3, 2012, págs. 251-271 [En línea: http://www.thamyris.uma.es/Thamyris3/VALVERDE.pdf. Fecha de consulta: $01 / 11 / 2020]$.

VERnANT, Jean-Pierre y Pierre VIDAL-NAQUET (1989), «El sujeto trágico: historicidad y transhistoricidad», en Mito y tragedia en la Grecia antigua, II, trad. de Ana Iriarte, Madrid, Taurus, págs. 83-95. 
La paradoja de Pierre Menard

Zimmermann, Bernhard (2012), Europa y la tragedia griega. De la representación ritual al teatro actual, trad. de José Antonio Padilla Villate, Madrid, Siglo XXI.

Fecha de recepción: 12/11/20.

Fecha de aceptación: 10/03/21. 